\title{
THE INFLUENCE OF THE ARCHITECTURAL STYLES OF THE MEDITERRANEAN COUNTRIES ON THE HERITAGE BUILDING' STYLES AT THE CITY OF MANSOURA, EGYPT
}

\author{
Mohanad Ali Mohamed FOUDA *
}

Architectural Department, Faculty of Engineering, Mansoura University, Egypt

\begin{abstract}
Mansoura, which is located northeast of the capital, Cairo, is considered one of the Egyptian cities that possesses a legacy. It is distinguished by its richness and architecture, and this is due to the important role that the city played as a mediator in the Delta Center in the agricultural trade Between farmers and merchants inside and outside Egypt, which made it an attractive city for residents and foreign communities, especially Greek and Italian. French, Belgian, and the interaction of foreign communities with the Egyptian population has an impact on social life inside the city This was reflected in the city's architecture and its surroundings, behind the heritage buildings that are a mixture of western and local civilization. Mansoura currently owns a number of heritage buildings registered in the heritage lists of the Ministry of Culture estimated at more than About one hundred heritage buildings of distinguished value, and the number of three registered antique buildings according to the Egyptian Ministry of Antiquities. It is noted, that it is dominated by those buildings classic Western styles that prevailed in Europe at that time Especially the countries of the northern Mediterranean, unlike buildings of a local and Islamic character

Keywords

The Architectural Styles, The Mediterranean Countries, The Heritage Building, Mansoura, Egypt.
\end{abstract}

\section{Introduction}

It is an analysis of the identity and styles of the heritage and archaeological buildings of the city of Mansoura and their classification, an attempt to assess the extent of the impact of the styles, The architecture of the Mediterranean countries that moved to the city through the children of the communities who settled the city on

Heritage buildings.

\section{Research Hypothesis}

Assuming the research is that the spread of Western classic styles in the facades of heritage and archaeological buildings in the city is due to their ownership by

Foreigners from different foreign communities.

2. Facade Architectural Formation Elements:

And through the elements of the architectural formation of the facades and the analysis of their design, formation and materials that are made of them, it is possible to determine

The architectural style to which the architectural façade belongs.

The elements of forming façades are divided into two main parts 1:

1. Basic elements such as:

* Corresponding author: engfac@mans.edu.eg 
1 "Kazantseeva , Tetyana and Ponkalo, Solomiya (2014)" CLASSIFICATION OF FACADE DECORATION OF SECESSION BUILDINGS BUILT BY I. LEVYNSKY COMPANY IN LVIV ", Journal ISSN: 1895-3247 Przestrzen I Forma -2014-NR- 21, Poland, 182.

A) Entrance portals to the building of all shapes, whether rectangular or knotted And the shape of the decorations in them, whether wooden or iron

B) The formation and design of openings in the façade, whether for windows or balcony doors.

C) Shaping and designing balcony fences in the façade and the materials used if they are

Burmese, iron, gypsum, or brick buildings, and one façade may contain

Balcony fences have more than one shape.

$\mathrm{S}$ (The corbels) located under the projection of the façade, their size, design and the decorations that bear them.

C) The upper end of the façade (building End), whether it is a dome or a frontpage, and the decorations it bears.

$\mathrm{H}$ (the arcades) - colonnades (if the ground floor is porticoes between the columns either It had balconies on the upper first floor, or protruding from the façade.

$\mathrm{X})$ The mayor at the front.

2. Decorative elements

A) The texture and material of the façade (rustication), whether it is stone, with different texture and shape of the stone or from

Whiteness, even if it contains drenches.

B) Mosaics and the artistic formation to which he belongs.

(V) Frankon with its types, Architectural Pediment (triangular, nodal, or fractured), which is above Openings (windows or doors) and it may be carried on columns or without, and it may bear floral motifs or faces Human. (Figure 1.)

W) Decorative cornices, whether those surrounding the openings or those that separate the floors or are present

On the course of the roof

(C) Geometric or floral ornaments.

\section{Conculsion}

Considering that Baroque architecture originated in Italy, neoclassical architecture emerged in the nineteenth century to revive Greek and Roman architecture, which had its origin in Greece and Italy, and the architecture of the Mediterranean basin was formed Deco originated in 
France, it can be said that $79.54 \%$ of the heritage and monumental buildings in Mansoura have been affected. Architecture of the Mediterranean countries.

- Although the Greeks were the largest foreign community at the city level, there is no dispute about what is common among the people of the city The Greeks owned property that it had seen, for most of them were renters of housing units, except for the Greek association that It acquired four buildings: the Greek Society building, the Acropolis / Hellenic Club (with an international style), and the Church Greek and Greek school building. Among the property returns for the buildings examined in the research, one residential building was found in AlMukhtalat neighborhood was built by Al-Khawaja Zdwafs (Greek). The Greek community used to build the Greek Society building and the school.

The Greek as well as Khawaja a Zadfos, a neoclassical style, and the school building shows the use of huge Corinthian columns The façades are topped by the triangular francophone. However, when the Hellenic Association rebuilt the club building in 1954 The Greek was built on the International Style. As for the Greek Church built in 1860, a movie Its remaining features indicate a specific or known model.

- Thanks to the presence of the Neo Baroque style in the heritage and monumental buildings of Mansoura, thanks to the help of the owners of the palaces And the important buildings for Italian architects and workers, as the Italians contributed to the design of $2360 \%$ of the total buildings Neo-Baroque at the city level, and their buildings, especially the palaces, are among the current features of the city of Mansoura and its symbol.

- The heritage buildings of a polling style, especially those that bear features of Islamic architecture, are considered to be six buildings from There are a total of nine buildings with a casting style "are the true embodiment of the mixture of local culture with Western culture as a product of interaction." The social and cultural incident between Egyptian citizens with the citizens of foreign communities, despite the value that this carries The buildings are of values, except that only six buildings remain after the demolition and destruction of the rest of the buildings in recent years.

The most important of them are (Michel Tadros Building mixed in) and 2 buildings belonging to the Faculty of Tourism and hotels, which are buildings bearing the features of architecture Islamic with the features of English architecture.

The Colonel's cottage buildings make up 5\% (six buildings) of the total heritage buildings in the city, and they are the most famous buildings.

It has the cities of the Canal, especially Port Said and Ismailia, and it is believed that the English are the reason for choosing the types of these buildings, especially a school The Military High 
School, which is under the administration of the English Principal, and the Sidi Saad Police Department, where the English were supervising at the time The British occupation of Egypt on the Interior Ministry, police departments and military schools. While the choice of the Colonel's model is due For the Belgians in the building of the headquarters of the Belgian Railways Director and an apartment building owned by a Frenchman called "Gerges Zgheib", he chose The same type of building is on Al-Mukhtalat Street. Currently, only three buildings of this type remain in the city, which are the school Military, Sidi Saad Police Station, and the mixed-use residential building.

\section{References:}

1) Sahar M. Dargham, Alexandrian Heritage and its Creative Role in Producing Contemporary Artworks For Fine Art Students, International Journal Of Architectural Engineering and Urban Research, Vol. 1, No. 1, 2018, pp. 1-3.

2) Iman Ali Rushdi El-Hawary, Architectural Vocabulary as Inspirational Elements of Multi-Purpose Design Courses (Case Study of Forms and Models Cours in the Department of Interior Design, Taibah University), International Journal of Architectural Engineering and Urban Research, Vol. 1, No. 2, 2018, pp. 18-21.

3) Aya Kamal El Din Amin Mohammed, Interaction Between Technology And Theatrical Architecture, International Journal of Architectural Engineering and Urban Research, Vol. 2, No. 1, 2019, pp. 10-15. 